\title{
Article \\ Synergistic Activity of Equol and Meropenem against Carbapenem-Resistant Escherichia coli
}

\author{
Hye-Rim $\operatorname{Kim}^{1}$ and Yong-Bin Eom ${ }^{1,2, * \mathbb{D}}$ \\ 1 Department of Medical Sciences, Graduate School, Soonchunhyang University, Asan 31538, Korea; \\ goa6471@naver.com \\ 2 Department of Biomedical Laboratory Science, College of Medical Sciences, Soonchunhyang University, \\ Asan 31538, Korea \\ * Correspondence: omnibin@sch.ac.kr; Tel.: +82-41-530-3039
}

Citation: Kim, H.-R.; Eom, Y.-B. Synergistic Activity of Equol and Meropenem against CarbapenemResistant Escherichia coli. Antibiotics 2021, 10, 161. https://doi.org/ 10.3390 /antibiotics10020161

Academic Editor: Krisztina M. Papp-Wallace

Received: 15 January 2021

Accepted: 2 February 2021

Published: 5 February 2021

Publisher's Note: MDPI stays neutral with regard to jurisdictional claims in published maps and institutional affiliations.

Copyright: (c) 2021 by the authors. Licensee MDPI, Basel, Switzerland. This article is an open access article distributed under the terms and conditions of the Creative Commons Attribution (CC BY) license (https:/ / creativecommons.org/licenses/by/ $4.0 /)$.

\begin{abstract}
The emergence of carbapenem-resistant Enterobacterales (CRE) seriously limits treatment options for bacterial infections. Combined drugs are an effective strategy to treat these resistant strains. This study aimed to evaluate the synergistic effect of equol and meropenem against carbapenemresistant Escherichia coli. First, this study investigated the antibacterial activity of carbapenems on clinically isolated E. coli strains by analyzing the minimum inhibitory concentrations (MICs). The E. coli strains were all resistant to carbapenem antibiotics. Therefore, we confirmed the cause of carbapenem resistance by detecting $b l a_{\mathrm{KPC}}$ and $b l a_{\mathrm{OXA}-48}$ among the carbapenemase genes using polymerase chain reaction (PCR) analysis. Checkerboard and time-kill analyses confirmed that equol restored the susceptibility of carbapenem-resistant E. coli to meropenem. Also, the transcription levels of specific carbapenemase genes in E. coli were significantly suppressed by equol. The study also evaluated the anti-virulence effects of equol on bacterial biofilm and motility through phenotypic and genotypic analyses. In conclusion, our results revealed that equol had a synergistic effect with meropenem on carbapenem-resistant E. coli. Therefore, this study suggests that equol is a promising antibiotic adjuvant that prevents the expression of carbapenemases and virulence factors in carbapenem-resistant E. coli.
\end{abstract}

Keywords: equol; carbapenem-resistant Escherichia coli; anti-bacterial; anti-virulence; synergistic activity

\section{Introduction}

Carbapenems are antibiotics used to treat multidrug-resistant (MDR) bacterial infections as a last resort. Therefore, the emergence and rapid spread of carbapenem-resistant Enterobacterales (CRE) are serious, global public health problems, associated with high mortality and morbidity due to treatment failure [1]. Carbapenem resistance is mediated by several factors such as porin loss, overexpressed efflux pumps, and carbapenemase production [2]. Among these factors, previous studies have reported that the production of carbapenemases is the main mechanism of carbapenem resistance [3,4]. According to the Ambler classification, carbapenemases can be mainly divided into three classes, class A (KPC; K. pneumoniae carbapenemase), class B (NDM; New Delhi metallo- $\beta$-lactamase, IMP; imipenem-resistant Pseudomonas carbapenemase and Verona integron-encoded metallo- $\beta$ lactamase (VIM)), and class D (OXA-48; oxacillinase-48) [3,5].

Escherichia coli belonging to the family Enterobacterales are symbiotic microorganisms commonly found in the gastrointestinal tract of warm-blooded organisms [6]. However, certain pathogenic strains can cause intestinal and extra-intestinal diseases such as urinary tract infections, meningitis, sepsis, and hemorrhagic colitis by damaging host cells through virulence factors [7]. The virulence factors of E. coli include flagella-mediated motility and curli fibers, which promote biofilm development and pathogenicity [8,9]. Biofilm, a community of sessile cells encased in extracellular polysaccharides self-produced by 
microorganisms, promotes resistance to antibiotics because it protects bacteria from antibiotics [10]. Previous studies have reported that biofilm formation can threaten human health by protecting microorganisms from the host immune system [11,12]. Moreover, these pathogenic E. coli strains also tend to acquire genes encoding extended-spectrum $\beta$-lactamases, carbapenemases, which hydrolyze or inactivate antibiotics, leading to antibiotic resistance [13]. A previous study showed that the resistance of E. coli to carbapenems, as well as to penicillins and cephalosporins, had increased [14].

The synergistic effect from the combination of two or more antibiotics may be an effective strategy to expand the antibacterial spectrum, minimize toxicity and prevent the emergence of MDR bacteria than when used alone [15]. Also, the combination of natural compounds and antibiotics is recommended to effectively treat MDR bacteria by minimizing adverse effects [16]. Many studies have reported synergistic effects from combinations of antibiotics and plant extracts [17-19]. Among them, a recent study found that the combination of antibiotics and natural phenolic compounds against $E$. coli showed synergistic effects [20]. Therefore, new effective compounds that can replace or synergize with existing antibiotics are urgently needed to treat carbapenem-resistant $E$. coli strains.

Isoflavone, a type of naturally occurring phenolic compound, is mainly sourced from soybeans, which contain daidzein, glycitein, and genistein [21]. In addition, isoflavone is called phytoestrogen because it is not only structurally similar to $17-\beta$-estradiol but also beneficial to human health. Equol $\left(4^{\prime}, 7\right.$-isoflavandiol) is a metabolite of daidzein formed by intestinal bacteria such as family Coriobacteriaceae and Lactobacillus sp. [22]. Previous studies demonstrated that equol exhibited more effective antioxidant and estrogenic activities than daidzein [23-25]. Moreover, many researchers have shown that equol had various biological activities such as anti-cancer, anti-inflammatory, and antimicrobial effects [26-30]. Although equol has biological activity, to the best of our knowledge, the anti-bacterial and anti-virulence effects of equol against carbapenem-resistant $E$. coli have not yet been reported.

This study assessed the synergistic and anti-virulence activities of equol against clinically isolated carbapenem-resistant E. coli strains. Also, this study investigated the mechanisms related to carbapenem-resistant $E$. coli and the synergistic effect of equol combined with meropenem.

\section{Results}

\subsection{Detection of Carbapenem-Resistant E. coli}

The MIC values of carbapenems (meropenem, imipenem, and ertapenem) for $E$. coli strains (KBN12P05816 and KBN12P06081) ranged from $\leq 4$ to $64 \mu \mathrm{g} / \mathrm{mL}$ (Table 1). Specifically, E. coli strains were identically inhibited in terms of cell growth by $90 \%$ at $16 \mu \mathrm{g} / \mathrm{mL}$ of meropenem and imipenem $\geq 4 \mu \mathrm{g} / \mathrm{mL}$. Also, E. coli strains (KBN12P05816 and $\mathrm{KBN} 12 \mathrm{P} 06081$ ) were inhibited by $90 \%$ at $32 \mu \mathrm{g} / \mathrm{mL}$ and $64 \mu \mathrm{g} / \mathrm{mL}$ concentrations of ertapenem, respectively. Therefore, according to the Clinical and Laboratory Standards Institute (CLSI) breakpoints, the E. coli strains were identified as carbapenem-resistant strains. Since the isolates were resistant to carbapenems, PCR was used to check for the presence of five major carbapenemase genes. As a result, $b l a_{\mathrm{KPC}}$ and $b l a_{\mathrm{OXA}-48}$ were detected in the clinically isolated E. coli strains (Table 2).

Table 1. Minimum inhibitory concentration (MIC in $\mu \mathrm{g} / \mathrm{mL}$ ) of carbapenems against clinically isolated E. coli strains.

\begin{tabular}{ccc}
\hline \multirow{2}{*}{ Carbapenem } & \multicolumn{2}{c}{ MIC $(\mu \mathrm{g} / \mathrm{mL})$} \\
\cline { 2 - 3 } & E. coli $\mathbf{~ K B N 1 2 P 0 5 8 1 6}$ & E. coli KBN12P06081 \\
\hline Meropenem & 16 & 16 \\
Imipenem & $\geq 4$ & $\geq 4$ \\
Ertapenem & 64 & 32 \\
\hline
\end{tabular}

MIC: minimum inhibitory concentration, KBN: Korea Biobank Network. 
Table 2. Detection of carbapenemase genes in E. coli strains as determined by PCR.

\begin{tabular}{ccc}
\hline \multirow{2}{*}{$\begin{array}{c}\text { Genes of } \\
\text { Carbapenemase }\end{array}$} & \multicolumn{2}{c}{ Bacterial Strains } \\
\cline { 2 - 3 } & E. coli KBN12P05816 & E. coli KBN12P06081 \\
\hline$b l a_{\mathrm{KPC}}$ & + & + \\
$b l a_{\mathrm{IMP}}$ & - & - \\
$b l a_{\mathrm{VIM}}$ & - & - \\
$b l a_{\mathrm{NDM}}$ & - & + \\
$b l a_{\mathrm{OXA}-48}$ & + & + \\
\hline
\end{tabular}

+; denotes the presence of the gene, - ; denotes the absence of the gene.

\subsection{Equol Restores the Susceptibility of Carbapenem-Resistant E. coli to Meropenem}

To determine the synergistic effect of equol and meropenem on carbapenem-resistant E. coli, checkerboard and time-kill analyses were performed. The minimum inhibitory concentrations (MICs) for equol and meropenem against carbapenem-resistant $E$. coli strains (KBN12P05816 and KBN12P06081) are shown in Table 3. The MIC is the lowest concentration of antimicrobial agents that inhibited cell growth by $90 \%$ compared to the control. The MIC of equol and meropenem for the two E. coli strains were 1024 and $16 \mu \mathrm{g} / \mathrm{mL}$, respectively. By measuring the absorbance, equol was found to inhibit the cell growth of $E$. coli in a concentration-dependent manner. When meropenem was combined with equol, the MIC of meropenem plus equol was 1 plus $256 \mu \mathrm{g} / \mathrm{mL}$, respectively, against the E. coli strains. The fractional inhibitory concentration (FIC) and FIC index (FICI) were calculated as described in the methods and the FICI of the equol and meropenem combination for all E. coli strains was 0.31 (Table 3). FICI values of less than or equal to 0.5 indicate a synergistic effect. Therefore, the FICI value for the combination of meropenem plus equol indicated a synergistic effect against these carbapenem-resistant $E$. coli strains. The analysis of the synergistic effects of meropenem and equol on E. coli KBN12P05816 over time showed that only the combined compounds were able to kill carbapenem-resistant $E$. coli. The antibacterial activity of the combined compounds was more than $6 \log _{10}$ compared to the control after $8 \mathrm{~h}$ (Figure 1).

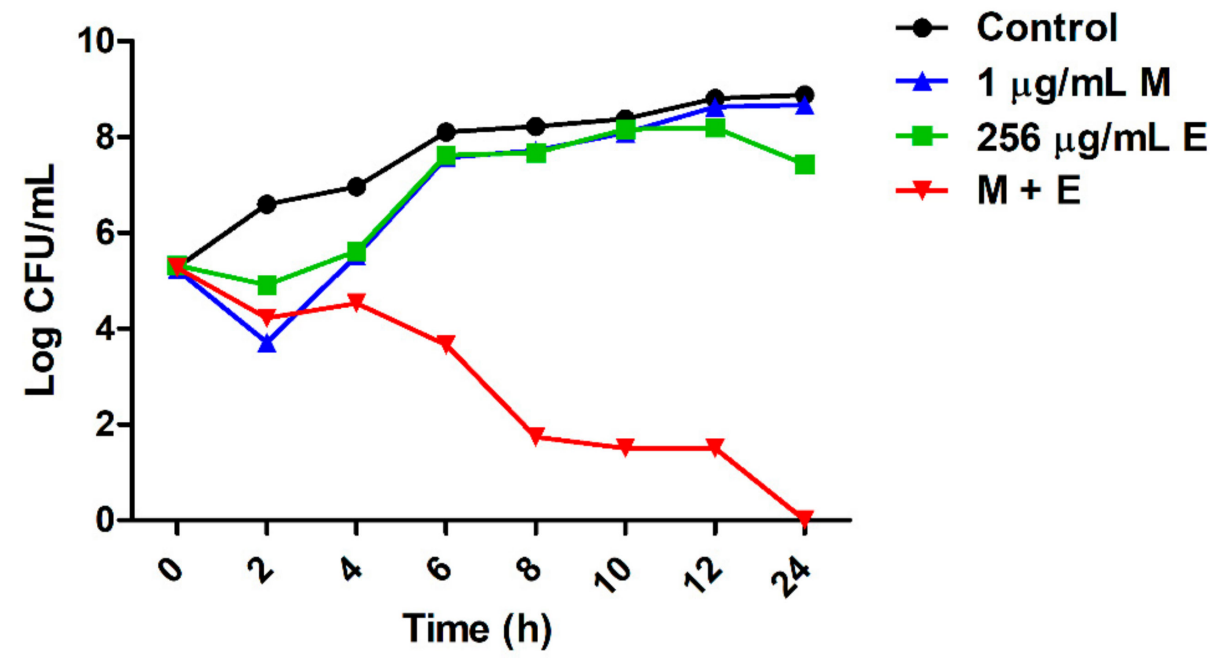

Figure 1. Synergistic effect of equol and meropenem against carbapenem-resistant E. coli. E. coli $\mathrm{KBN12P05816}$ strain treated with equol and meropenem at $37^{\circ} \mathrm{C}$. Each sample was plated with a spreader on MHA and incubated at $37^{\circ} \mathrm{C}$ for $24 \mathrm{~h}$. The $\mathrm{CFU} / \mathrm{mL}$ values were recorded. (•) Control;

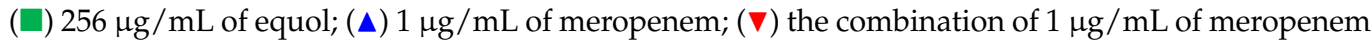
plus $256 \mu \mathrm{g} / \mathrm{mL}$ of equol. A sample not treated with equol and meropenem was used as the control. 
Table 3. Combinatory effects of equol and meropenem against carbapenem-resistant E. coli.

\begin{tabular}{cccccc}
\hline \multirow{2}{*}{ Strains } & \multicolumn{3}{c}{ MIC $(\mu \mathrm{g} / \mathrm{mL})$} & \multicolumn{2}{c}{ Meropenem + Equol } \\
\cline { 2 - 5 } & Meropenem & Equol & Meropenem + Equol & FIC Index & Interpretation \\
\hline E. coli KBN12P05816 & 16 & 1024 & $1+256$ & 0.31 & $\mathrm{~S}$ \\
E. coli KBN12P06081 & 16 & 1024 & $1+256$ & 0.31 & $\mathrm{~S}$ \\
\hline
\end{tabular}

\subsection{Anti-Biofilm Effects of Equol against Carbapenem-Resistant E. coli}

To investigate whether equol inhibited the biofilm of carbapenem-resistant $E$. coli, the biofilm biomass was quantified by crystal violet staining. As shown in Figure 2a, equol inhibited the biofilm formation of $E$. coli in a concentration-dependent manner compared to the control. Equol not only showed an inhibitory effect on biofilm formation but also showed an effect on preformed biofilm in a concentration-dependent manner (Figure $2 b$ ). More specifically, $256 \mu \mathrm{g} / \mathrm{mL}$ equol inhibited the biofilm formation of E. coli by $79.3 \%$ and the preformed biofilm of $E$. coli was inhibited by $76.7 \%$ in the presence of $256 \mu \mathrm{g} / \mathrm{mL}$ equol.

(a)

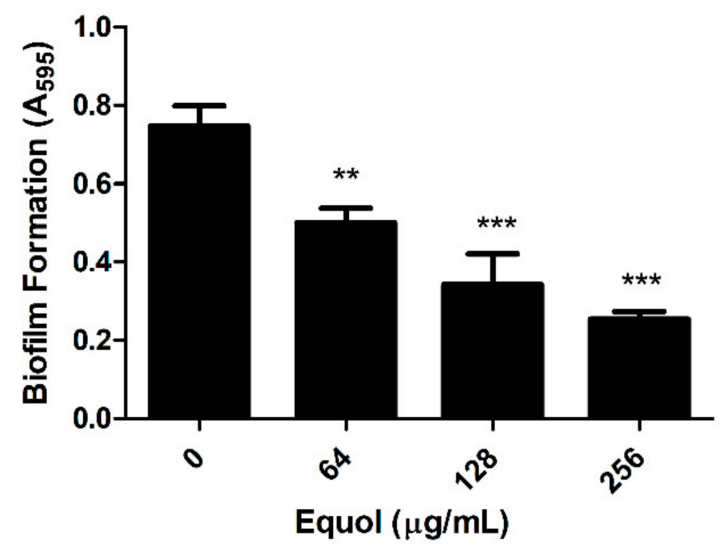

(b)

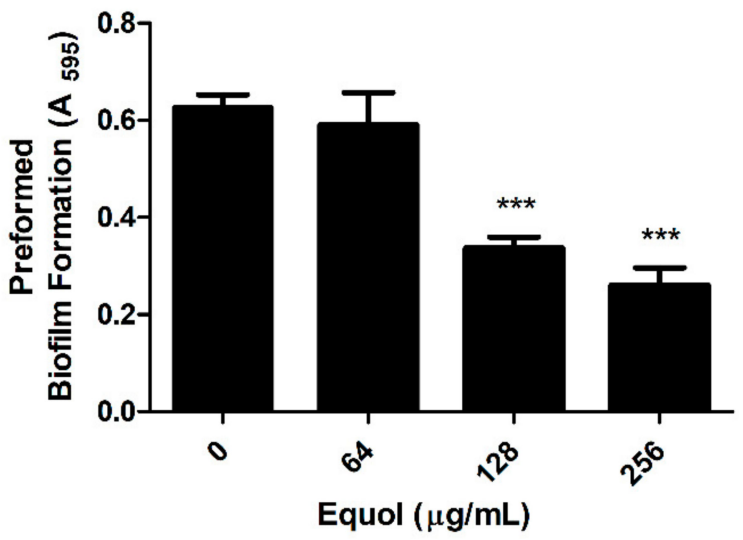

Figure 2. Anti-biofilm effect of equol against carbapenem-resistant $E$. coli. Biofilm inhibition (a) and biofilm eradication (b) of E. coli KBN12P05816 were quantified using crystal violet staining. E. coli was grown in TSB. The biofilm biomass was measured by the absorbance at $595 \mathrm{~nm}$. Asterisks $\left({ }^{*}\right)$ indicate statistically significant differences $\left({ }^{* *} p<0.01\right.$, and $\left.{ }^{* * *} p<0.001\right)$ from the control.

\subsection{Equol Suppresses the Motility of Carbapenem-Resistant E. coli}

The effect of equol on the motility of carbapenem-resistant $E$. coli was investigated as a phenotypic study. As shown in Figure 3, after an 18-h incubation, the migration distance was significantly decreased in semisolid agar plates containing equol in a dose-dependent manner (Figure 3a). Since the equol concentration used was at a sub-MIC, the decrease in motility was not due to impaired growth. In detail, the motility zones of $E$. coli treated with 64 and $128 \mu \mathrm{g} / \mathrm{mL}$ equol were 15.95 and $6.42 \mathrm{~mm}$, which were 31.4 and $72.4 \%$ smaller than that of the dimethyl sulfoxide (DMSO)-treated control (Figure 3b). Moreover, when E. coli was exposed to $256 \mu \mathrm{g} / \mathrm{mL}$ equol, motility was hardly observed.

\subsection{Equol Suppressed the Expression Levels of Carbapenemase- and Virulence-Related Genes in E. coli}

Quantitative polymerase chain reaction (qPCR) was performed to investigate the molecular mechanisms responsible for the carbapenem resistance of E. coli and the antibacterial and anti-virulence activities of equol (Figures 4 and 5). Equol significantly reduced the expression levels of the carbapenemase genes of E. coli, which produce KPC and OXA48 (Figure 4). More specifically, the expression level of the $b l a_{\mathrm{KPC}}$ gene was more effectively suppressed by equol than that of the $b l a_{\text {OXA- }} 48$ gene. However, the result of treatment with 
meropenem alone showed that the expression level of the carbapenemase gene was slightly decreased. Thus, our results show that equol inhibited the carbapenemase production in E. coli.

(a)

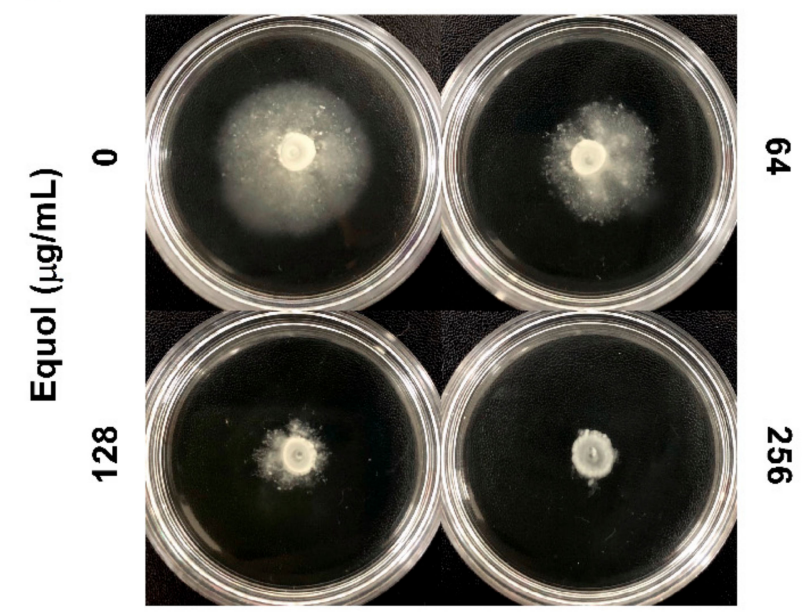

(b)

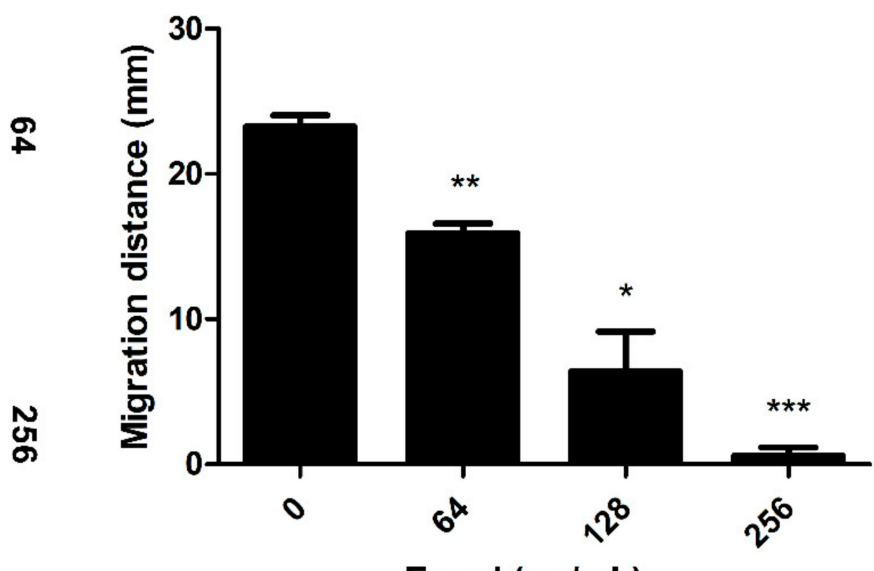

Equol $(\mu \mathrm{g} / \mathrm{mL})$

Figure 3. Effect of equol on the motility of E. coli. (a) Motility analyses were performed using semisolid agar plates containing equol at various concentrations. Carbapenem-resistant E. coli KBN12P05816 $\left(1 \times 10^{6} \mathrm{CFU} / \mathrm{mL}\right)$ was inoculated in the center of the semisolid agar containing equol. The inoculated plates were incubated at $37^{\circ} \mathrm{C}$ for $24 \mathrm{~h}$ and (b) the migration distance $(\mathrm{mm})$ was measured. The error bars represent the means and standard deviations (SDs). Asterisks $\left(^{*}\right)$ indicate statistically significant differences $\left({ }^{*} p<0.05,{ }^{* *} p<0.01\right.$ and $\left.{ }^{* * *} p<0.001\right)$ from the control.

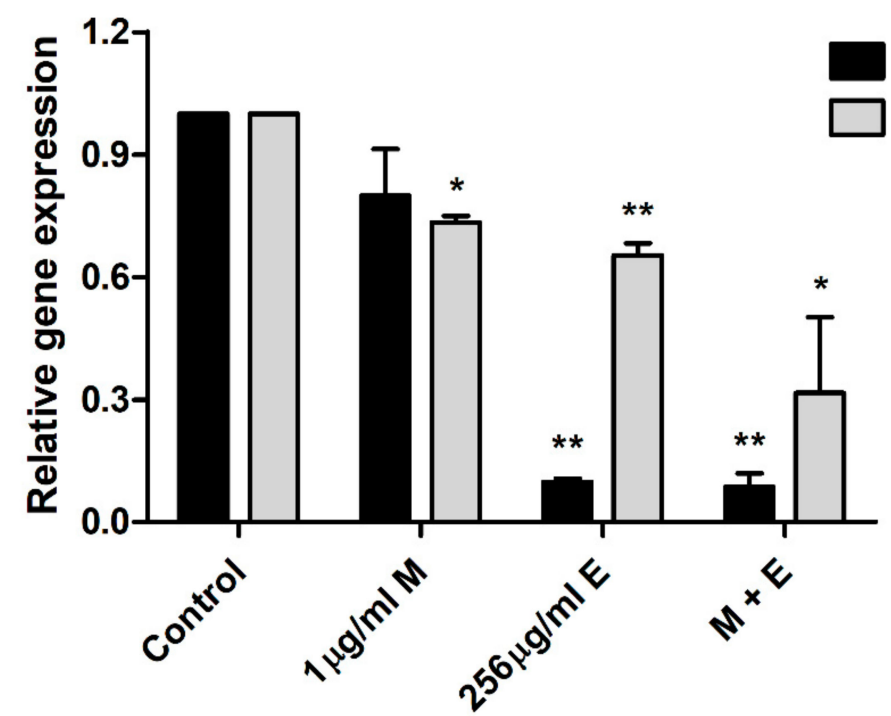

Figure 4. Transcriptional changes in the carbapenemase-related E. coli genes. After treatment with equol alone $(256 \mu \mathrm{g} / \mathrm{mL})$, meropenem alone $(1 \mu \mathrm{g} / \mathrm{mL})$, and the combination of $1 \mu \mathrm{g} / \mathrm{mL}$ of meropenem plus $256 \mu \mathrm{g} / \mathrm{mL}$ of equol, qPCR analysis of bla $a_{\mathrm{KPC}}$ and bla $a_{\mathrm{OXA}-48}$ genes in E. coli KBN12P05816 was performed. 16SrRNA was used to normalize the transcriptional levels of the target genes. The expression levels of the genes are expressed as fold-changes compared to the control and analyzed using the Student's $t$-test. The error bars represent the means and standard deviations (SDs). Asterisks $\left({ }^{*}\right)$ indicate statistically significant differences $\left({ }^{*} p<0.05\right.$ and $\left.{ }^{* *} p<0.01\right)$ from the control. 
(a)

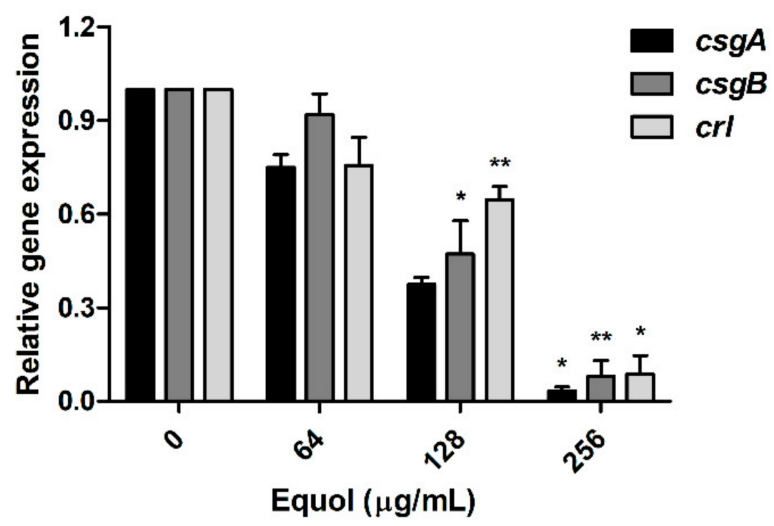

(b)

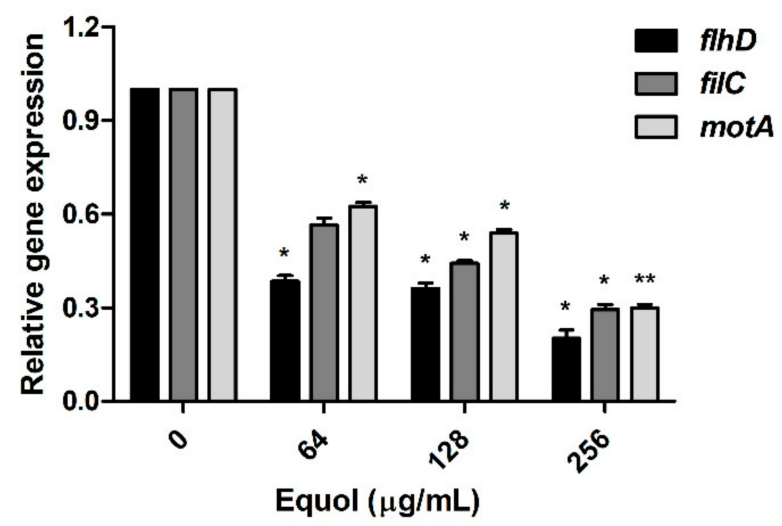

Figure 5. Transcriptional changes in the virulence-related E. coli genes. (a) Curli-related $(\operatorname{csg} A, \operatorname{csg} B$, and $\operatorname{crl})$ genes and (b) motility-related (fihD, filC, and mot A) genes. After treatment with various concentrations of equol ( 64 to $256 \mu \mathrm{g} / \mathrm{mL})$, qPCR analysis of curli- and motility-related genes in E. coli KBN12P05816 was performed. The transcription levels of the target genes were normalized to that of $16 S$ rRNA. The Student's $t$-test was conducted to analyze the gene expression between the samples and the control. The error bars represent the means and standard deviations (SDs). Asterisks $\left({ }^{*}\right)$ indicate statistically significant differences $\left({ }^{*} p<0.05\right.$ and $\left.{ }^{* *} p<0.01\right)$ from the control.

To investigate the anti-virulence effect, we examined the expression levels of curli and motility-related genes by equol. In the presence of $256 \mu \mathrm{g} / \mathrm{mL}$ equol, the expression level of $\operatorname{csg} A, \operatorname{csg} B$, and $\operatorname{crl}$ (curli-related genes) in E. coli was downregulated by 30.6-, 12.6-, and 11.5-fold, respectively (Figure 5a). As shown in Figure 5b, the motility-related genes were suppressed in a concentration-dependent manner by equol compared to the control. In particular, motility-related genes $(f l h D, f i l C$, and mot $A)$ were significantly downregulated 5.0-, 3.4-, and 3.4-fold, respectively, under the influence of $256 \mu \mathrm{g} / \mathrm{mL}$ equol. These results indicate that equol had an anti-virulence effect by inhibiting curli- and motilityrelated genes.

\section{Discussion}

The emergence of MDR pathogens is increasing due to the continued use of antimicrobial agents [31]. Especially, resistance to carbapenems, called the last resort of antibiotics, is widespread and has been found in many countries [1,32]. Previous studies have recommended synergistic drug combinations as key strategies for treating MDR pathogens $[33,34]$. Also, many studies have demonstrated that the development of antibiotic adjuvants that improve antibiotic activity can treat various resistant bacteria infections [35-37]. Therefore, antibacterial research and development such as studies on new antibiotic adjuvants should be promoted to prevent the emergence and spread of antibiotic resistance worldwide.

The types of antibiotic adjuvants studied to block antibiotic resistance include $\beta$ lactamase and efflux pump inhibitors, outer membrane permeabilizers, and anti-virulence drugs [36]. Among them, $\beta$-lactamase inhibitors are the most successful antibiotic adjuvants used clinically. Also, a previous study reported that anti-virulence drugs were less likely to cause resistant mutations because they do not target essential bacterial components [38]. This study suggested the possibility of equol as a new antibiotic adjuvant through investigations of the synergistic effect of meropenem and equol on carbapenem-resistant E. coli strains and the biological activity mechanisms of equol.

First, the MIC results showed that the clinically isolated E. coli strains were all resistant to carbapenem antibiotics (Table 1). Yoon et al. reported that CPE detected in Korea from 2011 to 2015 commonly has carbapenemases of KPC, NDM, and OXA-48 [39]. Another study reported that KPC-producing CREs were mainly found in K. pneumoniae and E. coli, and some E. coli also produced OXA-48 [40]. Similar to these studies, our study 
demonstrated the cause of carbapenem resistance by detecting $b l a_{\mathrm{KPC}}$ and $b l a_{\mathrm{OXA}-48}$ among carbapenemase genes using PCR (Table 2).

A previous study demonstrated that demethyltexasin, a human metabolite of soy isoflavones, showed strong synergistic effects on methicillin-resistant Staphylococcus aureus (MRSA) strains when combined with amoxicillin and oxacillin [41]. Likewise, equol is a metabolite of daidzein included in soy isoflavones [22]. Interestingly, previous studies have shown the antimicrobial activity of equol against microorganisms such as Clostridioides difficile and Candida albicans [29,30]. However, little has been reported about the combined effects of antibiotics and equol. Therefore, this study showed that equol and meropenem exhibited synergistic effects against carbapenem-resistant E. coli strains at a FICI of $<0.31$ using the checkerboard method (Table 3). The combination of equol and meropenem induced the meropenem-resistant E. coli strains to be susceptible to meropenem. In addition, the rate and extent of the synergistic effect over time were evaluated through the time killing assay (Figure 1).

This study performed both phenotypic and genotypic analyses to reveal the mechanisms of the synergistic effect of equol combined with meropenem. Biofilm, one of the virulence factors, is a microbial community formed in a self-produced extracellular matrix, which causes resistance to antibiotics [42]. A previous study reported that curli fibers encoded by the $\operatorname{csg} B A$ operon in $E$. coli were closely related to surface adhesion, cell aggregation, and biofilm formation [43]. In addition, other studies have shown that $\mathrm{Crl}$ protein interacted with RpoS and regulated $\operatorname{csg} D[44,45]$. Since $\operatorname{csg} D$ is directly required to activate the $\operatorname{csg} B A$ promoter, the $c r l$ gene will affect $\operatorname{csg} B A$ expression. Consistent with these previous findings, curli-related genes and biofilms showed a tendency to decrease in an equol-concentration-dependent manner (Figure 2). Moreover, our data showed that equol inhibited the expression of $\operatorname{csg} B$ and $\operatorname{csg} A$ more than $\operatorname{crl}$ (Figure 5a). These results indicate that the effect of equol directly influenced the genes encoding curli such as $\operatorname{cs} g B$ and $\operatorname{csg} A$.

The organelle responsible for the motility of E. coli is the flagellum, which is controlled by the flhDC operon [46]. FlhDC activates the transcription of flagella-related genes and several genes such as fliC [47]. A previous study reported that the $\Delta f l h D$ and $\Delta m o t A B \Delta f l i C$ mutant strains of E. coli MG1655 did not show motility [48]. First, our data showed that equol inhibited the motility of carbapenem-resistant E. coli at the phenotypic level (Figure 3). Next, the motility-related genes $(f l h D, f i l C$, and $\operatorname{mot} A$ ) were significantly downgraded by eqoul, which validated the phenotypic effect of equol (Figure 5b). Therefore, this study supported the anti-virulence effects of equol by showing that it inhibits biofilm and motility.

This study also evaluated the transcription levels of the carbapenemase genes by performing qPCR to determine whether the $b l a_{\mathrm{KPC}}$ and $b l a_{\mathrm{OXA}} 48$ genes were reduced by equol alone or in combination with meropenem (Figure 4). The gene expression levels of $b l a_{\mathrm{KPC}}$ and $b l a_{\mathrm{OXA}-48}$ were reduced by equol alone or in combination with meropenem. In contrast, meropenem alone hardly inhibited gene transcription. Particularly, the results of using equol alone or with meropenem significantly reduced the gene transcription level of $b l a_{\mathrm{KPC}}$ compared to control. For the $b l a_{\mathrm{OXA}} 48$ gene, combination therapy with equol and meropenem was more effective, leading to lower gene expression than either treatment alone. In a previous study, equol inhibited the growth and spore formation of Clostridioides difficile but had no effect on the expression of toxin-producing genes such as $t c d A, t c d B$, $c d t A$, and $c d t B$ [29]. However, we observed that equol inhibited the expression of the carbapenemase genes as well as the growth of carbapenem-resistant E. coli.

In summary, this study demonstrated the synergistic effect of equol with meropenem on carbapenem-resistant $E$. coli. It also inhibited the expression of specific carbapenemases in $E$. coli as the cause of carbapenem resistance. The anti-virulence effect of equol on E. coli was demonstrated through phenotypic and genotypic analyses. Therefore, equol showed the potential as an antibiotic adjuvant and anti-virulence agent. However, further in vivo studies are needed before equol can be used in the pharmaceutical field. Also, additional mechanistic studies are needed to identify the target of equol. 


\section{Materials and Methods}

\subsection{Organisms, Culture Conditions, and Reagents}

Two clinical isolates (E. coli strains KBN12P05816 and KBN12P06081) were provided by Gyeongsang National University Hospital Branch of the National Culture Collection for Pathogens (GNUH-NCCP). All strains were routinely sub-cultured on MacConkey agar (MAC; Difco, Becton, Dickinson and Company, Sparks, MD, USA) and inoculated into Tryptic Soy Broth (TSB; Difco, Becton, Dickinson, and Company) at $37^{\circ} \mathrm{C}$. The stock cultures were stored in TSB supplemented with $20 \%$ glycerol at $-80{ }^{\circ} \mathrm{C}$. (S)-Equol used in this study was purchased from TCI, Ltd. (Tokyo, Japan). Carbapenems (meropenem and ertapenem) were obtained from Sigma-Aldrich (St. Louis, MO, USA). (S)-Equol and meropenem were dissolved in DMSO and ertapenem was dissolved in distilled water. The final concentration of DMSO did not exceed $5 \%$ in all the experiments.

\subsection{Minimum Inhibitory Concentration Assay}

To determine the MIC of antimicrobial agents (meropenem, imipenem, ertapenem, and equol) against carbapenem-resistant $E$. coli strains, we used the broth microdilution method according to the CLSI guidelines M7-M9 [49,50]. The absorbance of the bacterial suspensions was measured at $600 \mathrm{~nm}$ with a Multiskan GO plate reader (Thermo Fisher Scientific, Waltham, MA, USA). The MIC value was defined as the lowest concentration of the antimicrobial agents that inhibited cell growth by $90 \%$ compared to the control.

\subsection{DNA Extraction and Polymerase Chain Reaction (PCR) Amplification}

DNA was extracted from the bacterial pellet using a QIAamp DNA Minikit (Qiagen, Valencia, CA, USA) according to the manufacturer's instructions. The PCR reaction mixture included $5 \mu \mathrm{L}$ of $10 \times$ PCR buffer (Perkin Elmer, Waltham, MA, USA), $3 \mu \mathrm{L}$ of $\mathrm{MgCl}_{2}$ (1.5 mM; Perkin Elmer), $2.5 \mu \mathrm{L}$ of dNTPs ( $2.5 \mathrm{mM}$; TakaraBio, Shiga, Japan), $5 \mu \mathrm{L}$ of each primer (10 pmole $/ \mu \mathrm{L}), 0.4 \mu \mathrm{L}$ of Ampli Taq Gold ( $5 \mathrm{U} / \mu \mathrm{L}$; Perkin Elmer), and $2 \mu \mathrm{L}$ of extracted DNA in a final volume of $50 \mu \mathrm{L}$. The primers used in this study are listed in Table 4. The thermal cycling conditions for PCR amplification consisted of an initial denaturation at $94{ }^{\circ} \mathrm{C}$ for $10 \mathrm{~min}$, followed by 36 cycles of denaturation at $94{ }^{\circ} \mathrm{C}$ for $30 \mathrm{~s}$, annealing at $55{ }^{\circ} \mathrm{C}$ for $30 \mathrm{~s}$, and extension at $72{ }^{\circ} \mathrm{C}$ for $50 \mathrm{~s}$, with a final elongation at $72{ }^{\circ} \mathrm{C}$ for $5 \mathrm{~min}$. The amplified PCR products were electrophoresed on a $2 \%$ agarose gel and visualized using the Gel Doc system (Bio-Rad, Hercules, CA, USA).

\subsection{Synergy Checkerboard Assay}

To assess the antimicrobial combinations, the synergy checkerboard assay was performed in 96-well microtiter plates according to a previous study with reference to the MICs of the two antimicrobial agents [59]. Briefly, bacterial cultures were suspended in TSB at a final concentration of $1 \times 10^{6} \mathrm{CFU} / \mathrm{mL}$ and distributed in plates with combinations of equol and meropenem using a two-fold serial dilution method. The concentrations of equol and meropenem used were the MIC and sub-MIC concentrations $(1 / 2,1 / 4,1 / 8$, $1 / 16$, and $1 / 32 \times \mathrm{MIC}$ ). Plates were incubated at $37^{\circ} \mathrm{C}$ for $24 \mathrm{~h}$. Growth inhibition was assessed using a Multiskan GO plate reader, and the FICI for $90 \%$ inhibition was calculated as follows: FIC of equol = MIC of equol in combination/MIC of equol alone, and FIC of meropenem $=$ MIC of meropenem in combination/MIC of meropenem alone. The FICI was defined as the FIC of equol plus the FIC of meropenem. The synergistic effect of equol in combination with meropenem against carbapenem-resistant $E$. coli was interpreted as follows. Synergy was indicated by a FICI of $\leq 0.5$, no interaction was indicated by a FICI from 0.5 to 4.0 , and antagonism was a FICI of $\geq 4.0$ [60]. 
Table 4. PCR primers used in this study.

\begin{tabular}{|c|c|c|c|c|}
\hline Primers & Target Gene & Primer Sequence $\left(5^{\prime}-3^{\prime}\right)$ & Annealing Temp. $\left({ }^{\circ} \mathrm{C}\right)$ & References \\
\hline \multirow[t]{10}{*}{ PCR primers } & $b l a_{\mathrm{KPC}}$ & F: CGTCTAGTTCTGCTGTCTTG & 54 & [51] \\
\hline & & R: CTTGTCATCCTTGTTAGGCG & & \\
\hline & $b l a_{\mathrm{IMP}}$ & F: GGAATAGAGTGGCTTAAYTC & 51 & [51] \\
\hline & & R: TCGGTTTAAYAAAACAACCACC & & \\
\hline & $b l a_{\mathrm{VIM}}$ & F: GATGGTGTTTGGTCGCATA & 56 & {$[51]$} \\
\hline & & R: CGAATGCGCAGCACCAG & & \\
\hline & $b l a_{\mathrm{NDM}}$ & F: GGTTTGGCGATCTGGTTTTC & 56 & [51] \\
\hline & & R: CGGAATGGCTCATCACGATC & & \\
\hline & $b l a_{\mathrm{OXA}-48}$ & F: GCGTGGTTAAGGATGAACAC & 55 & [51] \\
\hline & & R: CATCAAGTTCAACCCAACCG & & \\
\hline \multirow[t]{18}{*}{ qPCR primers } & $b l a_{\mathrm{KPC}}$ & F: GATACCACGTTCCGTCTGG & 57 & {$[52]$} \\
\hline & & R: GCAGGTTCCGGTTTTGTCTC & & \\
\hline & $b l a_{\mathrm{OXA}-48}$ & F: GGCACGTATGAGCAAGATGC & 59 & {$[53]$} \\
\hline & & R: GTTTGACAATACGCTGGCTGC & & \\
\hline & $\operatorname{csg} A$ & F: GGGCTCAGATGACAGCTCAAT & 59 & {$[54]$} \\
\hline & & R: GCCGTTCCACTGATCAAGAGTAG & & \\
\hline & $\operatorname{csg} B$ & F: CATAATTGGTCAAGCTGGGACTAA & 55 & {$[54]$} \\
\hline & & R: GCAACAACCGCCAAAAGTTT & & \\
\hline & $\mathrm{crl}$ & F: TTTCGATTGTCTGGCTGTATG & 54 & [55] \\
\hline & & R: CTTCAGATTCAGCGTCGTC & & \\
\hline & $\operatorname{mot} A$ & F: ACAGGTAGCGCGTTCTCACT & 58 & {$[54]$} \\
\hline & & R: AGCGTGGATAAACCGATACG & & \\
\hline & $f l h D$ & F: ACTTGCACAGCGTCTGATTG & 55 & [56] \\
\hline & & R: AGCTTAACCATTTGCGGAAG & & \\
\hline & fliC & F: ACAGCCTCTCGCTGATCACTCAAA & 61 & [57] \\
\hline & & R: GCGCTGTTAATACGCAAGCCAGAA & & \\
\hline & $16 S r R N A$ & F: CAGCTCGTGTCGTGAGATGT & 60 & {$[58]$} \\
\hline & & R: CGTAAGGGCCATGATGACTT & & \\
\hline
\end{tabular}

\subsection{Time-Kill Assay}

To evaluate the synergistic effect of equol and meropenem against E. coli, the time-kill assay was performed using 96-well polystyrene plates according to a previous study [50], with slight modifications. Briefly, E. coli suspensions $\left(1 \times 10^{6} \mathrm{CFU} / \mathrm{mL}\right)$ in TSB were exposed to antimicrobial agents $(1 \mu \mathrm{g} / \mathrm{mL}$ of meropenem, $256 \mu \mathrm{g} / \mathrm{mL}$ of equol, or the combination of $1 \mu \mathrm{g} / \mathrm{mL}$ of meropenem plus $256 \mu \mathrm{g} / \mathrm{mL}$ of equol) and incubated at $37^{\circ} \mathrm{C}$ for $24 \mathrm{~h}$. Samples were taken at time intervals of $0,2,4,6,8,10,12$, and $24 \mathrm{~h}$ and serially diluted in saline. Each sample was inoculated onto Mueller-Hinton agar (MHA; Difco, Becton, Dickinson and Company) plates using a spreader and incubated at $37^{\circ} \mathrm{C}$ for $18 \mathrm{~h}$. The number of colony-forming units (CFUs) of the samples was recorded.

\subsection{Biofilm Inhibition and Eradication Assay}

The crystal violet biofilm assay was performed in 96-well polystyrene plates (BD Falcon $^{\mathrm{TM}}$, Franklin Lakes, NJ, USA) as previously described [61,62], with minor modifications. Briefly, to determine the effect of equol on biofilm formation, the bacterial cell suspensions were inoculated into TSB containing different concentrations of equol (64 to $256 \mu \mathrm{g} / \mathrm{mL}$ ) at a density of $1 \times 10^{6} \mathrm{CFU} / \mathrm{mL}$ (total volume $=200 \mu \mathrm{L}$ ) and incubated at $37^{\circ} \mathrm{C}$ for $24 \mathrm{~h}$. After incubation, the non-adherent cells were removed by washing and fixed at $60^{\circ} \mathrm{C}$ for $1 \mathrm{~h}$. The fixed biofilms were stained with $0.5 \%$ crystal violet for $10 \mathrm{~min}$. Next, the stained biofilms were solubilized in $250 \mu \mathrm{L}$ of $33 \%$ acetic acid for $20 \mathrm{~min}$ and transferred from each well to a new plate. To evaluate the effect of equol on preformed biofilm, the bacterial cell suspensions were inoculated into the plates at a density of $1 \times 10^{6} \mathrm{CFU} / \mathrm{mL}$ and incubated at $37^{\circ} \mathrm{C}$ for $24 \mathrm{~h}$. After incubation, fresh TSB containing various concentrations of equol ( 64 to $256 \mu \mathrm{g} / \mathrm{mL}$ ) was added to each well. After further incubation for $24 \mathrm{~h}$, the biofilm was stained using crystal violet as described above. The total biofilm biomass was 
quantified by measuring the absorbance at a wavelength of $595 \mathrm{~nm}$ using a Multiskan GO plate reader. The sample not treated with equol was used as the control.

\subsection{Motility Inhibition Assay}

The effect of equol on the motility of E. coli was determined using Luria Bertani (LB; Difco, Becton, Dickinson and Company) plates containing $0.2 \%$ agar as described previously $[56,63]$, with minor modifications. Also, various concentrations of equol were included in the LB agar plates. Briefly, the bacterial cells were grown in TSB at $37^{\circ} \mathrm{C}$ for $24 \mathrm{~h}$. Subsequently, $5 \mu \mathrm{L}$ of bacterial cells $\left(1 \times 10^{6} \mathrm{CFU} / \mathrm{mL}\right)$ were inoculated onto LB agar plates and incubated at $37^{\circ} \mathrm{C}$ for $24 \mathrm{~h}$. Motility was assessed by measuring the migration distance $(\mathrm{mm})$ excluding the colony diameter after incubation.

\subsection{RNA Isolation}

For the transcriptional analysis of E. coli, total RNA was isolated using the following process [62]. Briefly, E. coli cells at a density of $1 \times 10^{6} \mathrm{CFU} / \mathrm{mL}$ in TSB were incubated at $37^{\circ} \mathrm{C}$ for $2 \mathrm{~h}$. After incubation, equol and meropenem were added to the bacterial cell suspensions and then further incubated at $37^{\circ} \mathrm{C}$ for $8 \mathrm{~h}$. In order to show the effect of the compounds remarkably, equol and meropenem were treated in the exponential phase (Supplementary Materials Figure S1). The cells were collected by centrifuging $2 \mathrm{~mL}$ of bacterial suspensions from each sample at $25,000 \mathrm{~g}$ for $90 \mathrm{~s}$ at $4{ }^{\circ} \mathrm{C}$. The total bacterial RNA was isolated and purified from the collected cells using the NucleoSpin RNA Mini Kit (Macherey-Nagel, Düren, Germany). The isolated total RNA was filtered using silica columns and treated with DNase to prevent DNA contamination. The BioDrop $\mu$ LITE (BioDrop Ltd., Cambridge, UK) was used to measure the quality and concentration of the isolated RNA samples.

\subsection{Quantitative Polymerase Chain Reaction ( $q P C R$ )}

QPCR was performed to evaluate the transcription levels of carbapenemase- and virulence-related genes in E. coli following equol and meropenem treatment. First, cDNA was synthesized with ReverTraAce qPCR RT Master Mix with gDNA Remover (TOYOBO, Japan) according to the manufacturer's manual using $1 \mu \mathrm{g}$ of total RNA. QPCR was performed using TOPreal ${ }^{\mathrm{TM}}$ qPCR 2X PreMIX (Enzynomics, Daejeon, Korea) to amplify cDNA in a StepOnePlus Real-Time PCR System (Applied Biosystems, Foster City, CA, USA). The primers used in this study are listed in Table 4. The 16S rRNA was used as the housekeeping gene. The qPCR conditions consisted of an initial denaturation at $95^{\circ} \mathrm{C}$ for $10 \mathrm{~min}$ followed by 40 cycles of denaturation at $95^{\circ} \mathrm{C}$ of $10 \mathrm{~s}$, annealing at $60^{\circ} \mathrm{C}$ for the $16 \mathrm{~S}$ $r R N A$ for $15 \mathrm{~s}$, and extension at $72{ }^{\circ} \mathrm{C}$ of $30 \mathrm{~s}$. Melting-curve analysis $\left(95^{\circ} \mathrm{C}\right.$ for $15 \mathrm{~s}, 60^{\circ} \mathrm{C}$ for $1 \mathrm{~min}$, and $95^{\circ} \mathrm{C}$ for $15 \mathrm{~s}$ ) was added at the end of the qPCR protocol. The annealing temperatures of the carbapenemase- and virulence-related genes are described in Table 4. The transcription levels of the target genes were normalized against those of $16 \mathrm{~S} r R N A$ and calculated using the $2^{-\Delta \Delta \mathrm{CT}}$ formula.

\subsection{Statistical Analysis}

The data are presented as means \pm standard deviations (SDs). To identify the significant differences between the treated and untreated samples, we used a one-way analysis of variance (ANOVA) followed by Dunnett's test. The qPCR data were analyzed using the Student's t-test. Also, 16S rRNA was used as an internal control gene and the relative expression level was analyzed using the $2^{-\Delta \Delta C T}$ method for the fold change calculation [64]. All statistical analyses were conducted through GraphPad Prism version 5 (GraphPad Software, La Jolla, CA, USA). Statistical significance was considered at ${ }^{*} p<0.05,{ }^{* *} p<0.01$, and ${ }^{* * *} p<0.001$.

Supplementary Materials: The following are available online at https:/ / www.mdpi.com/2079-638 2/10/2/161/s1, Figure S1. 
Author Contributions: Conceptualization, H.-R.K. and Y.-B.E.; methodology, H.-R.K. and Y.-B.E.; software, H.-R.K.; validation, H.-R.K. and Y.-B.E.; investigation, H.-R.K.; resources, Y.-B.E.; data curation, H.-R.K. and Y.-B.E.; writing-original draft preparation, H.-R.K.; writing-review and editing, Y.-B.E.; supervision, Y.-B.E.; project administration, Y.-B.E.; funding acquisition, Y.-B.E. All authors have read and agreed to the published version of the manuscript.

Funding: This research was supported by the Soonchunhyang University Research Fund and a National Research Foundation of Korea (NRF) grant funded by the Korean government (MSIT) [NRF-2020R1F1A1071977].

Institutional Review Board Statement: Not applicable.

Informed Consent Statement: Not applicable.

Data Availability Statement: All data are presented in the manuscript.

Conflicts of Interest: All authors declare no conflict of interest.

\section{References}

1. Van Duin, D.; Doi, Y. The global epidemiology of carbapenemase-producing Enterobacteriaceae. Virulence 2017, 8, 460-469. [CrossRef]

2. Baroud, M.; Dandache, I.; Araj, G.F.; Wakim, R.; Kanj, S.; Kanafani, Z.; Khairallah, M.; Sabra, A.; Shehab, M.; Dbaibo, G.; et al. Underlying mechanisms of carbapenem resistance in extended-spectrum beta-lactamase-producing Klebsiella pneumoniae and Escherichia coli isolates at a tertiary care centre in Lebanon: Role of OXA-48 and NDM-1 carbapenemases. Int. J. Antimicrob. Agents. 2013, 41, 75-79. [CrossRef]

3. Suay-Garcia, B.; Pérez-Gracia, M.T. Present and Future of Carbapenem-resistant Enterobacteriaceae (CRE) Infections. Antibiotics 2019, 8, 122. [CrossRef] [PubMed]

4. Logan, L.K.; Weinstein, R.A. The Epidemiology of Carbapenem-Resistant Enterobacteriaceae: The Impact and Evolution of a Global Menace. J. Infect. Dis. 2017, 215, S28-S36. [CrossRef] [PubMed]

5. Queenan, A.M.; Bush, K. Carbapenemases: The versatile beta-lactamases. Clin. Microbiol. Rev. 2007, 20, 440-458. [CrossRef] [PubMed]

6. Tenaillon, O.; Skurnik, D.; Picard, B.; Denamur, E. The population genetics of commensal Escherichia coli. Nat. Rev. Genet. 2010, 8, 207-217. [CrossRef]

7. Kaper, J.B.; Nataro, J.P.; Mobley, H.L.T. Pathogenic Escherichia coli. Nat. Rev. Genet. 2004, 2, 123-140. [CrossRef]

8. Gophna, U.; Barlev, M.; Seijffers, R.; Oelschlager, T.A.; Hacker, J.; Ron, E.Z. Curli Fibers Mediate Internalization ofEscherichia coli by Eukaryotic Cells. Infect. Immun. 2001, 69, 2659-2665. [CrossRef]

9. Kao, C.Y.; Lin, W.H.; Tseng, C.C.; Wu, A.B.; Wang, M.C.; Wu, J.-J. The complex interplay among bacterial motility and virulence factors in different Escherichia coli infections. Eur. J. Clin. Microbiol. Infect. Dis. 2014, 33, 2157-2162. [CrossRef] [PubMed]

10. Chen, L.; Wen, Y. The role of bacterial biofilm in persistent infections and control strategies. Int. J. Oral Sci. 2011, 3, 66-73. [CrossRef]

11. Li, X.-H.; Lee, J.-H. Antibiofilm agents: A new perspective for antimicrobial strategy. J. Microbiol. 2017, 55, 753-766. [CrossRef] [PubMed]

12. Donlan, R.M. Biofilms: Microbial Life on Surfaces. Emerg. Infect. Dis. 2002, 8, 881-890. [CrossRef]

13. Poirel, L.; Madec, J.Y.; Lupo, A.; Schink, A.K.; Kieffer, N.; Nordmann, P.; Schwarz, S. Antimicrobial resistance in Escherichia coli. Microbiol Spectr. 2018, 6. [CrossRef]

14. Rizzo, K.; Horwich-Scholefield, S.; Epson, E. Carbapenem and Cephalosporin Resistance among Enterobacteriaceae in HealthcareAssociated Infections, California, USA. Emerg. Infect. Dis. 2019, 25, 1389-1393. [CrossRef]

15. Sanhueza, L.; Melo, R.; Montero, R.; Maisey, K.; Mendoza, L.; Wilkens, M. Synergistic interactions between phenolic compounds identified in grape pomace extract with antibiotics of different classes against Staphylococcus aureus and Escherichia coli. PLoS ONE 2017, 12, e0172273. [CrossRef] [PubMed]

16. Teethaisong, Y.; Autarkool, N.; Sirichaiwetchakoon, K.; Krubphachaya, P.; Kupittayanant, S.; Eumkeb, G. Synergistic activity and mechanism of action of Stephania suberosa Forman extract and ampicillin combination against ampicillin-resistant Staphylococcus aureus. J. Biomed. Sci. 2014, 21, 90. [CrossRef]

17. Moussaoui, F.; Alaoui, T. Evaluation of antibacterial activity and synergistic effect between antibiotic and the essential oils of some medicinal plants. Asian Pac. J. Trop. Biomed. 2016, 6, 32-37. [CrossRef]

18. Aiyegoro, O.A.; Afolayan, A.J.; Okoh, A.I. Synergistic interaction of Helichrysum pedunculatum leaf extracts with antibiotics against wound infection associated bacteria. Biol. Res. 2009, 42, 327-338. [CrossRef] [PubMed]

19. Adwan, G.; Mhanna, M. Synergistic effects of plant extracts and antibiotics on Staphylococcus aureus strains isolated from clinical specimens. Asian Pac. J. Trop Med. 2009, 2, 46-51.

20. Hossain, M.A.; Park, H.C.; Park, S.W.; Park, S.C.; Seo, M.G.; Her, M.; Kang, J. Synergism of the combination of traditional antibiotics and novel phenolic compounds against Escherichia coli. Pathogens 2020, 9, 811. [CrossRef] 
21. Setchell, K.D.R.; Brown, N.M.; Desai, P.; Zimmer-Nechemias, L.; Wolfe, B.E.; Brashear, W.T.; Kirschner, A.S.; Cassidy, A.; Heubi, J.E. Bioavailability of Pure Isoflavones in Healthy Humans and Analysis of Commercial Soy Isoflavone Supplements. J. Nutr. 2001, 131, 1362S-1375S. [CrossRef] [PubMed]

22. Mayo, B.; Vázquez, L.; Flórez, A.B. Equol: A Bacterial Metabolite from the Daidzein Isoflavone and Its Presumed Beneficial Health Effects. Nutrients 2019, 11, 2231. [CrossRef] [PubMed]

23. Hwang, J.; Wang, J.; Morazzoni, P.; Hodis, H.N.; Sevanian, A. The phytoestrogen equol increases nitric oxide availability by inhibiting superoxide production: An antioxidant mechanism for cell-mediated LDL modification. Free. Radic. Biol. Med. 2003, 34, 1271-1282. [CrossRef]

24. Setchell, K.; Clerici, C.; Lephart, E.D.; Cole, S.J.; Heenan, C.; Castellani, D.; Wolfe, B.E.; Nechemias-Zimmer, L.; Brown, N.M.; Lund, T.D.; et al. S-Equol, a potent ligand for estrogen receptor $\beta$, is the exclusive enantiomeric form of the soy isoflavone metabolite produced by human intestinal bacterial flora. Am. J. Clin. Nutr. 2005, 81, 1072-1079. [CrossRef] [PubMed]

25. Jackson, R.L.; Greiwe, J.S.; Schwen, R.J. Emerging evidence of the health benefits of S-equol, an estrogen receptor $\beta$ agonist. Nutr. Rev. 2011, 69, 432-448. [CrossRef]

26. Chacko, B.K.; Chandler, R.T.; Mundhekar, A.; Khoo, N.; Pruitt, H.M.; Kucik, D.F.; Parks, D.A.; Kevil, C.G.; Barnes, S.; Patel, R.P. Revealing anti-inflammatory mechanisms of soy isoflavones by flow: Modulation of leukocyte-endothelial cell interactions. Am. J. Physiol. Circ. Physiol. 2005, 289, H908-H915. [CrossRef]

27. Itsumi, M.; Shiota, M.; Takeuchi, A.; Kashiwagi, E.; Inokuchi, J.; Tatsugami, K.; Kajioka, S.; Uchiumi, T.; Naito, S.; Eto, M.; et al. Equol inhibits prostate cancer growth through degradation of androgen receptor by S-phase kinase-associated protein 2. Cancer Sci. 2016, 107, 1022-1028. [CrossRef] [PubMed]

28. Charalambous, C.; Pitta, C.A.; Constantinou, A.I. Equol enhances tamoxifen's anti-tumor activity by induction of caspasemediated apoptosis in MCF-7 breast cancer cells. BMC Cancer 2013, 13, 238. [CrossRef]

29. Tanaka, Y.; Kimura, S.; Ishii, Y.; Tateda, K.; Yumi, T.; Soichiro, K.; Yoshikazu, I.; Kazuhiro, T. Equol inhibits growth and spore formation of Clostridioides difficile. J. Appl. Microbiol. 2019, 127, 932-940. [CrossRef]

30. Lee, J.A.; Chee, H.Y. In VitroAntifungal Activity of Equol againstCandida albicans. Mycobiology 2010, 38, 328-330. [CrossRef]

31. Roca, I.; Akova, M.; Baquero, F.; Carlet, J.; Cavaleri, M.; Coenen, S.; Cohen, J.H.M.; Findlay, D.; Gyssens, I.C.J.; Heure, O.E.; et al. The global threat of antimicrobial resistance: Science for intervention. New Microbes New Infect. 2015, 6, 22-29. [CrossRef]

32. Xu, Y.; Gu, B.; Huang, M.; Liu, H.; Xu, T.; Xia, W.; Wang, T. Epidemiology of carbapenem resistant Enterobacteriaceae (CRE) during 2000-2012 in Asia. J. Thorac. Dis. 2015, 7, 376-385. [PubMed]

33. Tyers, M.; Wright, G.D. Drug combinations: A strategy to extend the life of antibiotics in the 21st century. Nat. Rev. Genet. 2019, 17, 141-155. [CrossRef] [PubMed]

34. Torella, J.P.; Chait, R.; Kishony, R. Optimal drug synergy in antimicrobial treatments. PLoS Comput Biol. 2010, 6, e1000796. [CrossRef]

35. Lomovskaya, O.; Warren, M.S.; Lee, A.; Galazzo, J.; Fronko, R.; Lee, M.; Blais, J.; Cho, D.; Chamberland, S.; Renau, T.; et al Identification and Characterization of Inhibitors of Multidrug Resistance Efflux Pumps in Pseudomonas aeruginosa: Novel Agents for Combination Therapy. Antimicrob. Agents Chemother. 2001, 45, 105-116. [CrossRef]

36. González-Bello, C. Antibiotic adjuvants-A strategy to unlock bacterial resistance to antibiotics. Bioorganic Med. Chem. Lett. 2017, 27, 4221-4228. [CrossRef]

37. Mahmood, H.Y.; Jamshidi, S.; Sutton, J.M.; Rahman, K.M. Current Advances in Developing Inhibitors of Bacterial Multidrug Efflux Pumps. Curr. Med. Chem. 2016, 23, 1062-1081. [CrossRef]

38. Allen, R.C.; Popat, R.; Diggle, S.P.; Brown, S.P. Targeting virulence: Can we make evolution-proof drugs? Nat. Rev. Microbiol. 2014, 12, 300-308. [CrossRef]

39. Yoon, E.-J.; Yang, J.W.; Kim, J.O.; Lee, H.; Lee, K.J.; Jeong, S.H. Carbapenemase-producing Enterobacteriaceae in South Korea: A report from the National Laboratory Surveillance System. Futur. Microbiol. 2018, 13, 771-783. [CrossRef]

40. Park, S.H.; Kim, J.S.; Kim, H.S.; Yu, J.K.; Han, S.H.; Kang, M.J.; Hong, C.K.; Lee, S.M.; Oh, Y.H. Prevalence of carbapenem-resistant Enterobacteriaceae in Seoul, Korea. J. Bacteriol. Virol. 2020, 50, 107-116.

41. Rondevaldova, J.; Hummelova, J.; Tauchen, J.; Kokoska, L. In vitro anti-staphylococcal synergistic effect of isoflavone metabolite demethyltexasin with amoxicillin and oxacillin. Microb. Drug Resist. 2018, 24, 24-29. [CrossRef] [PubMed]

42. Stewart, P.S.; Costerton, J.W. Antibiotic resistance of bacteria in biofilms. Lancet 2001, 358, 135-138. [CrossRef]

43. Barnhart, M.M.; Chapman, M.R. Curli Biogenesis and Function. Annu. Rev. Microbiol. 2006, 60, 131-147. [CrossRef]

44. Arnqvist, A.; Olsén, A.; Pfeifer, J.; Russell, D.G.; Normark, S. The Crl protein activates cryptic genes for curli formation and fibronectin binding in Escherichia coli HB101. Mol. Microbiol. 2006, 6, 2443-2452. [CrossRef]

45. Robbe-Saule, V.; Jaumouille, V.; Prevost, M.C.; Guadagnini, S.; Talhouarne, C.; Mathout, H.; Kolb, A.; Norel, F. Crl activates transcription initiation of RpoS-regulated genes involved in the multicellular behavior of Salmonella enterica serovar Typhimurium. J. Bacteriol. 2006, 188, 3983-3994. [CrossRef]

46. Fahrner, K.A.; Berg, H.C. Mutations that stimulate flhDC expression in Escherichia coli K-12. J. Bacteriol. 2015, 197, 3087-3096. [CrossRef] [PubMed]

47. Fitzgerald, D.M.; Bonocora, R.P.; Wade, J.T. Comprehensive Mapping of the Escherichia coli Flagellar Regulatory Network. PLoS Genet. 2014, 10, e1004649. [CrossRef] 
48. Gauger, E.J.; Leatham, M.P.; Mercado-Lubo, R.; Laux, D.C.; Conway, T.; Cohen, P.S. Role of Motility and the flhDC Operon in Escherichia coli MG1655 Colonization of the Mouse Intestine. Infect. Immun. 2007, 75, 3315-3324. [CrossRef]

49. Clinical and Laboratory Standards Institute (CLSI). Methods for Dilution Antimicrobial Susceptibility Tests for Bacteria that Grow Aerobically; CLSI: Wayne, PA, USA, 2012.

50. Kim, H.R.; Eom, Y.B. Antifungal and anti-biofilm effects of 6-shogaol against Candida auris. J. Appl. Microbiol. 2020. [CrossRef]

51. Poirel, L.; Walsh, T.R.; Cuvillier, V.; Nordmann, P. Multiplex PCR for detection of acquired carbapenemase genes. Diagn. Microbiol. Infect. Dis. 2011, 70, 119-123. [CrossRef]

52. Hindiyeh, M.; Smollen, G.; Grossman, Z.; Ram, D.; Davidson, Y.; Mileguir, F.; Vax, M.; Ben David, D.; Tal, I.; Rahav, G.; et al. Rapid Detection of blaKPC Carbapenemase Genes by Real-Time PCR. J. Clin. Microbiol. 2008, 46, 2879-2883. [CrossRef] [PubMed]

53. Smiljanic, M.; Kaase, M.; Ahmad-Nejad, P.; Ghebremedhin, B. Comparison of in-house and commercial real time-PCR based carbapenemase gene detection methods in Enterobacteriaceae and non-fermenting gram-negative bacterial isolates. Ann. Clin. Microbiol. Antimicrob. 2017, 16, 48. [CrossRef]

54. Lee, J.-H.; Kim, Y.-G.; Raorane, C.J.; Ryu, S.Y.; Shim, J.-J.; Lee, J. The anti-biofilm and anti-virulence activities of trans-resveratrol and oxyresveratrol against uropathogenic Escherichia coli. Biofouling 2019, 35, 758-767. [CrossRef] [PubMed]

55. Knobl, T.; Moreno, A.M.; Paixao, R.; Gomes, T.A.; Vieira, M.A.; da Silva Leite, D.; Blanco, J.E.; Ferreira, A.J. Prevalence of avian pathogenic Escherichia coli (APEC) clone harboring sfa gene in Brazil. Sci. World J. 2012, 2012, 437342. [CrossRef]

56. Kakkanat, A.; Phan, M.-D.; Lo, A.W.; Beatson, S.A.; Schembri, M.A. Novel genes associated with enhanced motility of Escherichia coli ST131. PLoS ONE 2017, 12, e0176290. [CrossRef]

57. Lane, M.C.; Simms, A.N.; Mobley, H.L.T. Complex Interplay between Type 1 Fimbrial Expression and Flagellum-Mediated Motility of Uropathogenic Escherichia coli. J. Bacteriol. 2007, 189, 5523-5533. [CrossRef]

58. Shin, D.-S.; Eom, Y.-B. Antimicrobial and antibiofilm activities of Clostridium butyricum supernatant against Acinetobacter baumannii. Arch. Microbiol. 2020, 202, 1059-1068. [CrossRef]

59. Eumkeb, G.; Siriwong, S.; Thumanu, K. Synergistic activity of luteolin and amoxicillin combination against amoxicillin-resistant Escherichia coli and mode of action. J. Photochem. Photobiol. B Biol. 2012, 117, 247-253. [CrossRef] [PubMed]

60. Odds, F.C. Synergy, antagonism, and what the chequerboard puts between them. J. Antimicrob. Chemother. 2003, 52, 1. [CrossRef]

61. Woo, S.-G.; Lee, S.-Y.; Lim, K.-H.; Ha, E.-J.; Eom, Y.-B. Activity of novel inhibitors of Staphylococcus aureus biofilms. Folia Microbiol. 2017, 62, 157-167. [CrossRef] [PubMed]

62. Jang, H.; Eom, Y.-B. Repurposing auranofin to combat uropathogenic Escherichia coli biofilms. J. Appl. Microbiol. 2019, 127, 459-471. [CrossRef] [PubMed]

63. Kim, H.-R.; Shin, D.-S.; Jang, H.-I.; Eom, Y.-B. Anti-biofilm and anti-virulence effects of zerumbone against Acinetobacter baumannii. Microbiology 2020, 166, 717-726. [CrossRef] [PubMed]

64. Livak, K.J.; Schmittgen, T.D. Analysis of relative gene expression data using real-time quantitative PCR and the 2(T)(-Delta Delta C) method. Methods 2001, 25, 402-408. [CrossRef] [PubMed] 